\title{
Raúl Ruiz: Ontología de lo Fantástico. Territorios, Políticas Estéticas y Polisemia Visual
}

\author{
Raúl Ruiz: Ontology of the Fantastic. Territory, \\ Aesthetics Policies, and Visual Polysemy
}

\author{
Adolfo Vásquez Rocca \\ Universidad Andrés Bello - Universidad Complutense de Madrid \\ adolfovrocca@gmail.com
}

\begin{abstract}
Resumen - El cine de Raúl Ruiz nace de una continua reflexión acerca de los modos narrativos cinematográficos. Ruiz configura en Francia un cine exploratorio, experimental y barroco, que indaga en la falta de identidad y la pérdida del territorio. Es en su poética donde logra infiltrar su disidencia, su condición de exiliado metafísico, que encuentra su militancia en la lucha contra el núcleo ideológico de la teoría del conflicto central, que no es sino la operacionalización narrativa de los mecanismos de la competencia, característica del modelo neoliberal. La forma de polisemia visual que Ruiz pone en operación consiste en mirar una película cuya lógica narrativa aparente sigue siempre una misma historia, y cuyos vagabundeos, fallas, recorridos en zig-zag, se explican por su plan secreto, esto es por una película impostora, no explícita, cuyos puntos fuertes se ubican en los momentos débiles de la película aparente, para desde allí narrar otra historia, crear una obra que juegue con la película aparente, que la contradiga y especule sobre ella.
\end{abstract}

Palabras Clave: Cine, poética, semiótica, política, narrativa.

Abstract - The cinema of Raúl Ruiz comes from an ongoing reflection on the narrative modes of cinema. Ruiz sets in France an exploratory cinema, experimental and Baroque, which explores the lack of identity and loss of territory. It's in his poetic where he manages to infiltrate his dissent, his metaphysical exile, and his militancy in the struggle against the ideological core of the central theoretical conflict: the storytelling of the mechanisms of competition that is characteristic of neoliberal models. The form of visual polysemy that Ruiz put into operation consists of watching a film that has narrative logic that are apparently always the same; its wanderings, failures, zig-zag paths are explained by a sort of secret plan, an impostor film that is not explicit, and whose strengths lie in the weak moments of the film that seem to tell another story, creating a work that plays with the film, and that also contradicts it and speculates about it.

Keywords: Film, poetic, semiotics, politics, narrative. 
Es en esos mundos privados que harán su aparición unos films que el deber de misterio y la práctica de la clandestinidad volverán inclasificables, proteiformes, inagotables, en suma, porque estarán dotados de una polisemia infinita; duros de derribar, además, porque, como aquellas lombrices de tierra que, a falta de alimentos, se rejuvenecen, vuelven al huevo y renacen, esos films sabrán hacerse pequeños sin desaparecer. Con un poco de suerte, todos podremos ser testigos del renacimiento de ese cine, igual a sí mismo, y, por esa razón, más intratable que nunca.

Raúl Ruiz, Poética del Cine

\section{1.- EL CINE COMO ONTOLOGÍA DE LO FANTÁSTICO ${ }^{1}$}

Raúl Ruiz ha configurado con su filmografía un universo poético de sensibilidad barroca. Raúl Ruiz (2000), en su Poética del Cine, va más allá de la escritura literaria y la realización cinematográfica para reflexionar acerca de la naturaleza de la narrativa y la estructura de todo relato posible. Ruiz esboza modelos analíticos en torno a nociones claves como la «decisión» (lo que inflexiona una acción en un sentido o en otro) y el "conflicto» (lo que organiza de manera elemental dos acciones entre sí) (Aumont, 152). El cineasta ofrece una poética del cine que insiste en la capacidad polisémica de narrar que tienen las imágenes. Su cine nace de una continua reflexión acerca del lenguaje y los modos narrativos del cine, así como de su gusto por la experimentación. Hay en el cine un poder de subversión lógica que Raúl Ruiz pone en acción implacablemente en cada una de sus películas, sin saber siquiera —o al menos sin parecer importarle- si habrá un público para ellas.

Las obras de arte «son [para Ruiz] organizaciones imaginarias del mundo, que, para activarse, necesitan entrar en contacto con uno o varios seres humanos» (Ruiz, 90). Las hay, además, de distintas clases: los «delitos imaginarios», los «mundos perfectos», la invención de nuevas maneras de hacer arte, las «exploraciones de nuevos territorios", para las que Ruiz propone tipologías o esbozos de catálogos. De este modo el realizador - como teórico y experimentador- resucita las preocupaciones de Robbe-Grillet ${ }^{2}$ (159) en torno a la lógica de lo narrativo, la semántica de los mundos posibles y el arte de las acciones narradas.

\footnotetext{
Este texto corresponde a conversaciones sostenidas por el autor con Raúl Ruiz —inicialmente en la ciudad de Valparaíso en el 2000 - con ocasión de la presentación de su libro Poética del Cine, en el marco de una retrospectiva que las Universidades de la zona organizaron como homenaje al realizador chileno. Algunas de estas conversaciones, junto a Artículos y Estudios especializados, han aparecido en diversas revistas de cine y semiótica - principalmente del medio europeo-, las que son reseñadas en el presente artículo. Sin embargo algunas de estas conversaciones y análisis permanecen inéditos esperando su próxima publicación bajo la forma de libro.

Debe recordarse que Ruiz entre los años 1969 y 1972 tuvo a su cargo la Cátedra de Cine del Instituto de Arte de la Universidad Católica de Valparaíso.

2 La teoría de los generadores, adoptada por los «Nouveaux romanciers» en los años 70 , afirmaba que la novela podía ser escrita a partir de algunos términos que, por juegos paragramáticos, engendraban otros, hasta proveer todo el material necesario para la ficción.
} 
Raúl Ruiz ha elaborado tantas películas como teorías. Son famosas sus disquisiciones como una extensión muchas veces más compleja que sus mismas imágenes. En el cine de Ruiz subyace una densidad teórica que da cuenta de su diálogo con intelectuales franceses relativamente «marginales». Más que de «influencias», se trata de una sensibilidad compartida que problematiza nociones como «estereotipo» y «alteridad» —el tema del doble-, ya presente en el trabajo de Ruiz en Chile y potenciado por su diálogo con Klossowski y Baudrillard. En Ruiz la impostura ocupa un lugar central, su cine es un cine de dobles, un cine de la alteridad y la alteración, de la metamorfosis y la alotopía propios de los textos y las retóricas barrocas con su particular predilección por la alegoría.

La amistad y colaboración de Ruiz con el historiador y teórico del arte Jean-Louis Schefer ha conducido también a un estudio intensivo de las teorías de la percepción y de la historia general de la «representación», como han sido concebidas por teólogos y filósofos. Sin embargo, su compromiso con estos universos académicos y especulativos es altamente selectivo y, en cierta forma, pragmático. Por ejemplo, de Klossowski toma su interés por el tableau vivant (cuadro viviente), la representación que «tiene vida propia», tema e iconografía de La hipótesis del cuadro robado (Francia, 1978), uno de sus filmes más emblemáticos, nombrado una de las diez mejores películas de la década. Mientras que Klossowski — un «disidente» católico, traductor de Nietzsche y de Wittgenstein y también novelista erótico - ve al estereotipo como un residuo del simulacro o un proceso esencialmente mágico de representación visual, Ruiz lo interpreta como un proceso a la vez epistemológico y político. En particular lo identifica con el surgimiento de estereotipos sociales y políticos de Chile antes y durante la Unidad Popular. Ruiz, a partir de allí, desarrolla una investigación - así como una filmografía - tanto en un nivel histórico como conceptual, que indudablemente influyó de vuelta a Schefer y Baudrillard, que en Simulacros y simulación, incluye la observación Ruiziana: «En todas partes vivimos en un universo extremadamente semejante al original —allí las cosas son dobladas por su propio guión».

\section{2.- CEREMONIAS, POLÍTICAS ESTÉTICAS Y POLISEMIA VISUAL}

¿Qué es un símbolo? Decir una cosa y significar otra. ¿Por qué no decirlo directamente? Por la simple razón de que ciertos fenómenos tienden a disolverse si nos acercamos a ellos sin ceremonia

El cine de Ruiz es un cine de paradojas, de relatos laberínticos y recursivos. Ellos dan forma a una poética cuya retórica consiste precisamente, a partir de juegos y contradicciones lógicas, en deconstruir las convenciones canonizadas por el cine norteamericano, convenciones que giran en torno al eje ideológico de la teoría del conflicto central, que, a su vez, no es sino la operacionalización narrativa de los mecanismos de la competencia, característica del modelo neoliberal. El cine de Ruiz es así un «cine del desacuerdo» —un cine de resistencia- con relación a los cánones narrativos tradicionales. Todo arte es, como señala Ranciere ${ }^{3}$, un préstamo ejecutado por un trabajo perceptivo y discursivo

«El destino del cine como arte» (Entrevista a Jacques Ranciere). Declaraciones a su amiga Emmanuel Burdeau y al editor de "Cahiers du Cinéma» Jean-Michel Frodon (1/12/2004), publicada en la edición 598 de la revista francesa. 
obtenido de diferentes tipos de entretenimientos, rituales o ceremonias. La especificidad del cine es haber podido desarrollarse bajo una forma no experimental, a gran escala, aprovechando su estatus de entretenimiento. Si el cine ha podido negociar ciertas transacciones poéticas entre regímenes de narración y descripción diferentes es debido a que ha podido negociar tranquilamente la relación entre entretenimiento y arte, porque nunca ha sufrido el peso de demandas artísticas, porque ha estado encerrado en un espacio de diversión de masas, ha escapado de la urgencia política que ha conducido a la literatura, a la pintura, al teatro o a la música hasta respuestas globales. Incluso el imperativo industrial que obliga a los directores a rodar guiones impuestos, bajo reglas determinadas, ha otorgado al cine una especie de abrigo para definir una «modernidad tranquila». Sólo el cine de autor constituyó una ruptura con este estatus industrial. Durante los años 60, el éxito de la política de los autores coincidió con el gran momento de cuestionamiento del arte. El cine tomó sus préstamos del tumulto de las vanguardias o de las exigencias políticas para constituirse en un arte que preserva su identidad incluso a través de la revolución de sus modos de descripción y narración. Este es el clima en que surge la «disidencia de Ruiz» con los dispositivos narrativos del cine complacientes con las rutinas de la mirada, con la planificación clásica. Lo que existe es la puesta en escena, es decir, el estilo, redefinido por cada cineasta e incluso por cada película; el contenido hace a la forma, de lo que se trata en cada escena es de dominar el espacio y en el montaje dominar el tiempo: «Una historia es propiamente esa relación de interioridad que pone toda imagen en relación con cualquier otra, que permite estar ahí donde no se ha estado, producir todas las conexiones que no han sido producidas, volver a contar de otro modo todas las historias> [...] La historia es la promesa de una omnipresencia y de una omnipotencia que son al mismo tiempo una impotencia de actuar sobre cualquier otro presente que el de su realización» (Ranciere, 236).

De allí que en el cine de Ruiz la conciencia sea un objeto movedizo, inestable, en fuga; un objeto que depende de un aparato perceptual que puede ser engañado, manipulado, embriagado, y que construye la realidad con retazos de todo ello: recuerdos distorsionados, datos perdidos, sueños inconclusos, sistema de orientación y medición en continuo colapso. Si el cine de Ruiz supone una mirada sobre la alienación, no lo hace desde una teoría social, sino desde una perspectiva epistemológica y una sospecha óptica. Este procedimiento parte de la convicción de que el cine no debería ser utilizado para narrar linealmente historias sino para conmover, a través de los movimientos sensibles de la cámara y la capacidad polisémica de las imágenes, los estados del ánimo y la conciencia de los espectadores. Ruiz propone un nuevo modelo narrativo, que se sustenta en lo onírico de los fragmentos inconexos y discontinuos, de los pasajes inagotables de la mente, ilusiones y pensamientos errantes.

El cine de Ruiz en sus inicios se propuso explorar las formas de alienación, la violencia subrepticia, su gestualidad solipsista y su lenguaje tautológico: un programa "antropológico», según la expresión usada con más frecuencia en la historiografía del cine. $\mathrm{Y}$ aunque no se puede discutir que esta lectura funciona vigorosamente con Tres tristes tigres (1968), a 30 años de distancia resulta evidente que no es la única, y desde luego no la última. Hay en esta película unos sujetos deambulantes, pero sobre todo hay unas conciencias desbaratadas, unas identidades al borde del naufragio que se buscan desesperadamente a través de gestos mecánicos y frases sin fondo, como lo harán más tarde los frustrados personajes de Diálogo de exiliados (Francia, 1974). 
Quizás esta percepción de la identidad chilena permitió a Ruiz descubrir que el quebrantamiento de lo que llamábamos conciencia era un fenómeno más universal que local. O quizás esa visión formó siempre parte de su poética. Poética que pudo configurar, tras su exilio, en París, donde demostró la integridad de sus convicciones artísticas al filmar en todos los formatos y sistemas de producción siempre según su visión personal, sin detenerse ni capitular un ápice.

Ruiz ha venido, en estas últimas décadas, filmando la descomposición del relato en tanto artificio productor de sentido y ordenador de la realidad. No se trata solo de los «grandes relatos» de que hablaba Lyotard, sino de todos los relatos posibles, empezando por (o terminando con) el propio cine. A diferencia de los autores empeñados en desnudar la mecánica del acto artístico (Peter Greenaway) o de revelar la intervención del aparato fílmico (Abbas Kiarostami), Ruiz denuncia la mentira de la óptica: sus películas hablan del cine no como medio artístico, sino como artificio del ojo. En ellas son mucho más importantes los encuadres que las situaciones o los personajes, la imagen que el argumento.

En realidad, los personajes ruizianos son discursos, identidades vaciadas en fragmentos de discursos. El ciego "que siempre mentía» (Las tres coronas del marinero), la adivina "que ve el pasado" (Imágenes de muerte), la tía psicoanalista (Genealogía de un crimen), el diablo que habla como argentino (Nadie dijo nada), etc. no pueden ser entendidos con arreglo a la dramaturgia o la psicología tradicional, sino solo con relación a la construcción precaria de identidad del discurso.

En la que probablemente sea su película más cercana a la comedia pura, El techo de la ballena, Ruiz lleva esa visión hasta sus límites, con un grupo de científicos que investiga a una tribu cuyo idioma consiste en una sola palabra. Esta clase de humor, esta burla de los supuestos culturales y civilizatorios, esta mofa de las formalidades del "conocimiento» está en la base del programa estético de Ruiz. Y si ello desconcierta a muchos espectadores, solo se debe al supuesto de que el humor no forma parte de los atributos del gran arte. Como todos los creadores mayores, Ruiz se anticipó en muchos años a la filosofía y a la ciencia social. Su mundo intelectual estaba enteramente formado mucho antes de que Lyotard describiera en 1979 La condición postmoderna. Y aun así, ese mundo está en el centro del posmodernismo del mismo modo que Picasso pudo estar en el centro del cubismo: anunciando, junto con su expansión máxima, la proximidad de su superación.

Lyotard al utilizar los términos «relato», «grandes relatos» y «metarrelato» se dirigía a un mismo referente: los discursos legitimadores a nivel ideológico, social, político y científico. «Un metarrelato es, [nos decía Lyotard], una gran narración con pretensiones justificatorias y explicativas de ciertas instituciones o creencias compartidas» (Diéguez, 177-205). Un Léxico último — si se quiere emplear la terminología de Rorty-. El discurso legitimador se caracteriza no por ser prosa narrativa sino principalmente prosa argumentativa. Todo intento de realizar políticamente un sistema ideológico tiene en su interior el germen del totalitarismo, la determinación de la pluralidad a partir de un solo punto de vista que se impone por todos los medios posibles.

Estamos en presencia de la muerte de los metarrelatos, en la que la razón y su sujeto — como detentador de la unidad y la totalidad — vuelan en pedazos. Si se mira con más detención, se trata de un movimiento de deconstrucción del cogito y de las utopías de unidad. Aquí debe subrayarse el irreductible carácter local de todo discurso, acuerdo y legitimación. Esto nos instala al margen del discurso de la tradición literaria (estética) 
occidental. Tal vez de ahí provenga la vitalidad de los engendros del discurso periférico, en Los Márgenes de la Filosofía (1988) como dirá Derrida.

La destotalización del mundo moderno exige eliminar la nostalgia del todo y la unidad. Como características de lo que Foucault ha denominado la episteme $e^{4}$ posmoderna podrían mencionarse las siguientes: deconstrucción, descentración, diseminación, discontinuidad, dispersión. Estos términos expresan el rechazo del cogito que se había convertido en algo propio y característico de la filosofía occidental, con lo cual surge una «obsesión epistemológica» por los fragmentos.

La ruptura con la razón totalizadora supone el abandono de los grands récits, es decir, de las grandes narraciones, del discurso con pretensiones de universalidad, y el retorno de las petites histoires. Tras el fin de los grandes proyectos aparece una diversidad de pequeños proyectos que alientan modestas pretensiones. Aquí se insiste en el irreductible pluralismo de los juegos de lenguaje, acentuando el carácter local de todo discurso, y la imposibilidad de un comienzo absoluto en la historia de la razón. Ya no existe un lenguaje general, sino multiplicidad de discursos. Y ha perdido credibilidad la idea de un discurso, consenso, historia o progreso en singular: en su lugar aparece una pluralidad de ámbitos de discurso y narraciones (Vásquez Rocca, «La posmodernidad: nuevo régimen de verdad»).

\section{3.- PLAN SECRETO, SINFONÍA DRAMÁTICA Y LÓGICA NARRATIVA}

Todos los males del hombre provienen de una sola causa, la cual consiste en su incapacidad de permanecer en reposo en su cuarto

Pascal, Pensamientos

Si propongo esta modesta defensa del aburrimiento, es justamente porque las películas que me interesan provocan a veces algo parecido. Digamos que poseen una elevada calidad del aburrimiento. Aquellos de ustedes que han visto películas de Snow, Ozu o Tarkovsky, saben de qué estoy hablando. Otro tanto puede decirse de Warhol o de Straub.

Raúl Ruiz, Poética del Cine

El universo narrativo ruiziano está hecho de historias que se entrelazan y se cruzan reingresando sobre sí mismas, al modo de las paradojas auto referenciales tan propias de la lógica contemporánea - donde se pone en entredicho el principio de no contradicción, que tiranizó durante siglos la lógica de Occidente-, dando, de este modo, lugar a una especie de polisemia visual donde se explora — por ejemplo - la idea, tan cara para la física cuántica, de que no existe simplemente una historia para el universo, sino una co-

\footnotetext{
«La épistémè no es una teoría general de toda ciencia posible o de todo enunciado científico posible, sino la normatividad interna de las diferentes actividades científicas tal como han sido practicadas y de lo que las ha hecho históricamente posibles». Cf. Foucault, Michel, «La vie: L'expèrience et la science», en Revue de Métaphysique et de Morale, 1 enero-marzo de 1985, R. 10.

«En una cultura en un momento dado, nunca hay más que una sola épistémè, que define las condiciones de posibilidad de todo saber. Sea el que se manifiesta en una teoría o aquel que está silenciosamente envuelto en una práctica» (Foucault, 179).
} 
lección de historias posibles para el universo, todas igualmente reales. A esta posibilidad, la de internarse en los zigzagueos de estas historias, que se van armando a la manera de una urdiembre ontológica que entrelaza las diversas dimensiones de una realidad que en último término, y en una apelación chamánica, Ruiz dirá que obedece a un plan secreto, plan que al modo de un enigma siguen todas sus películas.

La forma de polisemia visual que Ruiz pone en operación consiste en mirar una película cuya lógica narrativa aparente sigue siempre más o menos una historia, y cuyos vagabundeos, fallas, recorridos en zig-zag, se explican por su plan secreto. Este plan solo puede ser otra película no explícita cuyos puntos fuertes se ubican en los momentos débiles de la película aparente. Imaginemos que todos estos momentos de relajo o distracción narren otra historia, formen una obra que juegue con la película aparente, que la contradiga y especule sobre ella (Vásquez Rocca, «Raúl Ruiz, l'enfant terrible»).

Ruiz deconstruye también las claves con que el análisis simbólico, metafórico o psicoanalítico han contaminado la hermenéutica fílmica.

Ruiz descoloca al espectador, lo reinstala en la situación de un lector de texto. Se está, pues, aquí ante la idea del cine como escritura, del film como texto. De un texto como tejido en perpetuo urdimiento, como tejido que se hace, se trabaja a sí mismo y deshace al sujeto en su textura: una araña que se disolvería ella misma en las secreciones constructivas de su tela.

Ahora bien, en el tejido mismo de las situaciones fílmicas, la exuberancia de las ramificaciones determina espacios vacíos, callejones por los que circulará el relato, bajo el modo de una ausencia (Rojas, 143). Paralelamente, un relato impostor, simulador y parásito finge ser el principio organizador de nudos y desenlaces. Entre las conexiones voluntarias de imágenes y de palabras circula un flujo de analogías inconmensurables.

Del mismo modo como con la autorreflexividad, en las estructuras recursivas y los dispositivos circulares, propios de las películas de Ruiz, se produce un juego de espejos en que una obra se da al interior de otra obra, sin un centro (eje) primario de organización. Asimismo, en la novela postmoderna se da el fenómeno de la novela dentro de la novela, donde ésta se convierte en ensayo sobre la novela o, más exactamente, en un ensayo sobre cómo dejar de escribir novelas. Novelas sin relatos, ni progresión lineal, llena —o más bien vacía- de tiempos muertos y de personajes que deambulan sin que algo particularmente interesante pareciera necesitar acontecerles, situación que conduce al lector no avisado a una cierta perplejidad y desazón.

Tal huelga de acontecimientos (Baudrillard) —o desdramatización de la realidadproviene tanto del desmantelamiento de la teoría del conflicto central, como del tratamiento recursivo de la cuestión de la decisión en la posmodernidad, en lo cual cabe reconocer una deuda fundamental con las ideas de Schopenhauer, quien, al igual que Nietzsche, constituye un antecedente temprano y fundamental de la posmodernidad.

\section{4.- CINE, POLÍTICA Y TERRITORIO}

La retórica ruiziana es bella, cultivada, irónica. Chile, o mejor, su ausencia está presente en todos sus filmes desde, Diálogo de Exiliados (1974), hasta Las Tres Coronas del Marinero (1983). 
La identidad a la deriva parece ser el sino de los tripulantes del Funchaleuse, el barco de los muertos, en Las tres coronas del marinero: el Imitador, el Otro, el oficial que arrienda a su madre, el capitán que borda letras, el niño-sabio, el negro que sabe la Biblia de memoria; el mismo barco que un día se hunde, y al siguiente resucita, para una mañana cualquiera regresar a Valparaíso, donde el Marinero halla su casa clausurada. Todas estas son sin duda imágenes del exilio, pero no en un mero sentido territorial sino en uno metafísico y existencial, en «una historia que se despliega hasta el infinito, en una opacidad propia de las ficciones del exilio" (Ruiz). Nada extraño en Ruiz — hijo de un capitán de marina y cineasta involucrado, durante su carrera en Chile, en la indagación de los modos de la identidad nacional (Mouesca) — quien «encara la pérdida del territorio desde el no-territorio, la superficie líquida de un barco errante y el cuento de un marinero que busca cumplir un sueño imposible» (Cavallo, 213). Y por si se cree que esta mirada elude los alcances políticos que marcan el exilio, reténganse la carta de la madre de alquiler: «Honrarán a su madre según estos preceptos. Desarrollar la memoria, no la egoísta, sino la colectiva. Si alguno recuerda algo algo, hará como si nada hubiera ocurrido. Todos deben comprender la misma, que se acuse de ignorancia. Honrarán siempre con la imaginación, inventando nuevos modos de unirse...» (Ruiz, Las Tres Coronas del Marinero).

El cine de Ruiz es político en su sentido identitario, esto es, en que sus películas son chilenas o latinoamericanas precisamente por el sentido de la pérdida del territorio. El cine de Ruiz no es un cine militante sino exploratorio, indaga en la falta de identidad, que es esencialmente la condición del exiliado, la que Ruiz compartió desde 1974. De allí que el tema de la primera película que filmó al dejar Chile como refugiado político fuera Diálogos de exiliados, hecha en París, y "políticamente incorrecta».

La película comienza con una cita de Brecht, que afirma que los inmigrantes son los mejores dialécticos. Diálogos de exiliados procede de manera suficientemente dialéctica como para ganarse la antipatía de los espectadores chilenos y no chilenos por igual. Como Ruiz hace notar en una entrevista de 1975, este acercamiento condujo tanto a malentendidos políticos como también a una narrativa difusa que presenta otras dificultades. Pero también creó ciertas posibilidades analíticas:

Esta es una película con una historia: un grupo de exiliados toma un rehén para impedirle que cante. Alrededor de esto, desarrollé una narrativa que juega en contra de la pirámide de dirección usual en el cine comercial corriente, con su protagonista principal y personajes secundarios. Aquí, distintos personajes están en primer plano en distintos momentos y la puesta en escena se esfuerza por eliminar la pirámide, en tanto juego con el contraste entre una dirección rigurosa y la informalidad natural del diálogo y la actuación. La unión de estos elementos contradictorios crea un cierto potencial, una capacidad de análisis (Ruiz cit. en De los Ríos, 213).

Con una atmósfera que recuerda Paris nous appartient (1960), gente sentada alrededor de mesas en pequeños departamentos, y un ritmo dramático estructurado en torno a llegadas y partidas (con puertas y ventanas como ejes centrales de la puesta en escena), este largometraje logra disipar mucha de la tensión generada con su premisa central (un cantante chileno emigrante y fascista que irrita constantemente a los chilenos que lo ayudan) a través de su foco narrativo cambiante. Esto resulta en una interesante ambigüedad de tratamiento que la convierte, como Ruiz hace notar, en una película política que se abstiene de la propaganda y del espectáculo. 
Ahora bien, aunque el cine de Ruiz parece estar dirigido a una élite, como es propio esperar de un director de culto, solo para intelectuales, prácticamente inalcanzable, Televisión Nacional de Chile se permitió producir y exhibir - aunque en un horario prácticamente de trasnoche- la serie - en rigor un film en capítulos- escrita por Ruiz para dicha estación. Se trata de Recta Provincia (haciendo referencia a los brujos de Chiloé) donde se registran giros y modismos del Chile profundo, pero todo desde una extrañeza radical, que nos hace volver a los «días de campo" como extranjeros, como extraterrestres que por primera vez vieran y oyeran caer una gotera, hablar al diablo y se solazaran con viejas historias contadas por el viento arremolinado, desenterradas de cuentos y mitos campesinos, relatos de viejas castas de demonios que se arrimaron por estas tierras en tiempos de pillaje y muertes cruentas de conquistadores e indios belicosos que dieron lugar a ríos de sangre mística entre el Biobío y el Toltén. La historia arranca cuando una madre y su hijo descubren un hueso que se puede tocar como flauta y que al hacerlo, pide que reconstruyan su cuerpo. Este es Chile. Es la Recta Provincia, donde todos cojeamos, asegura un diablo. La realidad, en consecuencia, es obtusa y ladeada. Un lugar donde muertos y vivos comparten, donde lo único perfecto son largos planos de montaña, bosque y cielo. Así, Recta Provincia narra una historia localizada en el campo de la zona central de Chile, con referencias no solo a nuestro folclor sino a tradiciones antropológicas ancestrales de todo el mundo y que en su cine reverberan con la majestad de la presencia muda de la cordillera de los Andes como horizonte mítico de nuestro aislamiento, de nuestra condición de isla al fin del mundo, donde proliferan los cuentos de buques fantasmas, de almas en pena, de huesos repartidos en esta extraña patria, «en la fértil provincia y señalada [...] donde la gente es tan soberbia, gallarda y belicosa, que no ha sido por rey jamás regida, ni a extranjero dominio sometida» (Ruiz, Recta Provincia), solo ha sido dominada por pequeños periodos bajo regímenes de excepción, el más largo de esos gobiernos es el dominio espiritual de la tierra de los brujos y demonios que en la mitología de Chiloé se ha dado en llamar la Recta Provincia. Así el relato de Ruiz se eleva de la anécdota local de los mitos fundacionales a los arquetipos universales de la creación del mundo, constituyendo no solo una cosmovisión sino una cosmogonía y sobre todo un relato mayor sobre los orígenes del mal (Vásquez Rocca, «Raúl Ruiz: La Recta Provincia»).

\section{5.- «CAHIERS DU CÍNEMA» Y EL RECONOCIMIENTO DE LA CRÍTICA EUROPEA}

Por todo lo anterior, para nadie en el ambiente cinematográfico fue sorpresa cuando Raúl Ruiz, radicado en París, a fines de la década del ochenta acababa de ser galardonado con un "premio" especial, recibido por pocos cineastas en la historia del cine mundial: Cahiers du Cinéma, la mítica revista de cine francesa, representativa del nivel más avanzado entre la crítica europea, venía a dedicar un número entero a Ruiz. Homenaje, sin duda, al cineasta «francés» más importante del momento, el único que está planteando líneas renovadoras en un arte reducido a un grupo de grandes clásicos (Rohmer, Bresson, Godard), pero que ha sido escaso en nuevos autores. 
A manera de homenaje a Raúl Ruiz se incluye aquí la traducción del prefacio del número especial de la revista Cahiers, escrito por el redactor en jefe, Serge Toubiana, y titulado «El caso Ruiz»; el texto es el siguiente:

Un número entero consagrado a un cineasta, eso no se veía desde hacía tiempo en los 'Cahiers'. Recordamos sí el especial Eisenstein en 1971, el número 300 de Godard y los 'fuera de serie': Welles, Pasolini, o Hitchcock. Ahora es el turno de Raúl Ruiz, el cineasta más prolífico de nuestro tiempo, aquel cuya filmografía es casi imposible establecer, por lo diversa y multiforme que resulta ser su producción desde hace más de veinte años. Raúl Ruiz, un cineasta que navega entre Lisboa, Rótterdam y París, lejos de su lugar de partida, Santiago de Chile, donde no se siente a gusto para vivir.

Es un cineasta cuya manera de producir es de una elasticidad sin igual: desde un pedido para televisión a pequeñas producciones regionales o locales (en el extranjero o en Francia), siempre manteniendo una actividad casi regular en el INA (Instituto Nacional Audiovisual), donde él hace funcionar un mini-laboratorio de 'nuevas imágenes', como lo hacía Mélies, por ejemplo; a esto debe agregarse su actividad académica, como Profesor visitante de Cine en la Universidad de Harvard y como conferencista en las más importantes universidades de Europa y los Estados Unidos.

Todo el cine de Ruiz es un cine 'torcido', porque es visto a través de curiosos prismas, siempre desnaturalizando la perspectiva clásica: un cine de «tuerto» (que es el título de una de sus películas). Así como cada plano ruiziano lleva una marca, una cifra, o un secreto (un poco como Welles, y los más grandes), una torsión, él propone ejes de toma de vista imposibles, utiliza todos los trucos; la banda sonora a su vez es polifónica, multilingüe, resuena con tantos acentos diferentes como co-producciones o personajes hay en la ficción (Toubiana, 5).

\section{6.- RUIZ Y LA DECONSTRUCCIÓN DE LA TEORÍA DEL CONFLICTO CENTRAL}

La teoría del conflicto central ${ }^{5}$ tiende a hacernos creer que el mundo tiene una cierta armonía y que esta armonía es alterada por la violencia de la voluntad de atacar a otro para conseguir algo.

Reseñemos el primer enunciado de esta teoría: yo quiero algo, si quiero algo trato de hacerlo, siempre alguien se opondrá, yo me llamo protagonista, el que se opone se llama antagonista; luchamos, esta lucha se agudiza, mientras más se agudiza todo lo que pasa en torno a la película se va concentrando. Uno se va interesando en esto, uno quiere saber si ganará uno u otro (como en un partido) y finalmente gana uno; para esto, claro está, hay un complejo sistema de normas acerca de curvas de crisis, de clímax, etc. A partir de ese momento, a través de diferentes digresiones, todos los elementos de la historia se ordenan alrededor del conflicto central.

Para decirlo sumariamente y de paso develar uno de los supuestos ideológicos en los que se funda la teoría del conflicto central, digamos desde ya que el cine de Ruiz refuta o si se quiere deconstruye (en una maniobra de desmantelamiento) algunas tesis epistemológicas, como la creencia en un mundo armónico y en una sola historia posible para el universo - al modo determinista. El cine de Ruiz, sin ser un cine de tesis es un

5 Una historia tiene lugar cuando alguien quiere algo y otro no quiere que lo obtenga. 
cine postmoderno. En sincronía con este «momento postmoderno", que implica articular relatos que podrían ser excelentes ilustraciones de las más contemporáneas teorías semánticas, como la de Kripke acerca de los mundos posibles, el cine de Ruiz se emancipa de las pretensiones de los «grandes relatos», de las ideologías totalizadoras derivadas de la voluntad de sistema. En su cine, subyace más bien una fascinación por las aparentes «pequeñas historias»; un rechazo del racionalismo de la modernidad en favor de un juego de signos y fragmentos, de una síntesis de lo dispar, de dobles codificaciones. En el cine de Ruiz se deja entrever la transformación estética de la sensibilidad de la Ilustración por la del Cinismo contemporáneo, en el que la ironía — pensemos en Rorty $(1996)^{6}$ — es una de las claves hermenéuticas para aproximarse al cine de Ruiz y entender los constantes «guiños» que está haciendo al espectador. Donde había una moral de la linealidad y univocidad — esto, en el marco de la lógica narrativa-, Ruiz introduce pluralidad, multiplicidad y contradicción, duplicidad de sentidos y tensión en lugar de inerciales códigos narrativos, tiranizados por el principio de identidad y de no contradicción (preconizados por la Lógica de Aristóteles); El cine de Ruiz se abre al «así y también asá» en lugar del unívoco "o lo uno o lo otro", elementos con doble funcionalidad, cruces de lugar en vez de unicidad clara. Para decirlo con un artefacto de Parra: «Ni sí ni no, sino todo lo contrario. El último reducto posible para la filosofía», en este caso para el cine, después de la decretada muerte del cine (Peter Greenaway).

Ahora bien ¿dónde esta el origen de todo esto? El origen ideológico-estético de la teoría del conflicto central puede encontrarse a fines del siglo XIX en la crítica al teatro antiguo y la defensa del teatro moderno hecho por Bernard Shaw y por Ibsen, aunque en rigor es posible rastrearla hasta el mismo Aristóteles. Los alcances de la misma nos aproximan a ciertas concepciones filosóficas, a las que Ruiz llama ficciones; una de ellas es que el mundo se construye a fuerza de choques y colisiones. Como se ve esta teoría apunta a lo que se podría llamar una «presunción de hostilidad». Del principio de hostilidad constante en las historias cinematográficas resulta una dificultad suplementaria: la de obligarnos a tomar partido.

La teoría del conflicto central produce una ficción deportiva y se propone embarcarnos en un viaje en el que, prisioneros de la voluntad del protagonista, estamos sometidos a las diferentes etapas del conflicto en el cual el héroe es a la vez guardián y cautivo.

Esta teoría se convierte no solo en el esquema de toda narración teatral, sino también en el esquema que impera todas las formas de ser del hombre moderno, y aquí ocurre algo curioso, se ha llegado al punto en que los sistemas narrativos están influyendo en la manera de ser y de actuar de la gente, la gente se inspira en las películas para hacer cosas.

Hemos llegado a un punto en el que el arte, y en particular el cine, ha vuelto a cumplir la función que alguna vez tuvo, la de engendrar formas de vida, no solo individuales sino colectivas e institucionales en tanto configura no solo un discurso, sino también una fuerza productora de «realidades» o al menos de relatos. Lo que en el marco constructivista es más o menos lo mismo: La realidad es una narrativa exitosa. Es así pues que, como lo ha hecho notar Oscar Wilde, «la vida imita al arte».

Ortega, por su parte, en «El Origen Deportivo del Estado» señala que los hombres jóvenes, que son activos y enérgicos, luchan, compiten; de esto surge un cierto interés por el deporte; luego, una vez que los hombres fijan ciertas reglas de esos deportes y esos

6 Rorty, Richard, Contingencia, ironía y solidaridad. Barcelona: Editorial Paidós, 1996. Medio impreso. 
deportes son todos el mismo y a la misma hora, eso se llama obra de teatro, cuadro, se llama música; y de ahí cuando se retira el placer —lo lúdico—, el sentido de la fiesta, ahí aparecen las Instituciones jurídicas y aparece el Estado. Hoy, frente a cierta decadencia de los estamentos del Estado podríamos decir, que si bien al parecer nuestras instituciones han nacido de ciertas películas, de seguro que éstas no han sido las mejores.

Por ahí se comienzan a entender las razones por las cuales Ruiz ha militado queriendo cambiar la estructura narrativa del cine — su lucha contra la teoría del conflicto central- La primera razón es que este no es un problema trivial y tiene directa relación con el ethos del hombre que vive en una cultura y que se nutre de cierto cine - de paso digamos, si es que no se ha advertido, que la teoría del conflicto central se corresponde con la ideología norteamericana y con el modo como surge o se producen las instituciones que dan forma a nuestra sociedad occidental.

El cine de Ruiz, cuyo conflicto central es su lucha con la teoría del conflicto central, supone una mirada sobre la alienación, mirada que no solo asume la forma de profunda crítica social, sino que también revisa, en vistas a desmantelar, las bases epistemológicas en que se funda el proyecto racionalista de la modernidad.

La estrategia deconstructiva de Ruiz consiste en proponernos como señuelo narrativo de toda narración posible, el que una historia «fantasma» - impostora- permanezca «legible». ¿Qué pasaría si se hace un filme de manera tal que al llegar al final se puedan remontar sus planos en el orden inverso, que la inversión sea una especie de respuesta al filme proyectado al derecho? El filme pasado en orden inverso privilegia aquella función en la que todo nos lleva a adentrarnos en el plano y a quedarnos en él (o a completarlo nosotros mismos de manera que cuando pasemos al próximo tengamos la impresión de empezar un filme diferente) (De los Ríos, 308).

Ahora bien, la posibilidad de componer un cine poético a partir de estas maniobras deconstructivas depende de la capacidad combinatoria para generar historias. Todos nosotros somos poseedores de verdaderos tesoros; de obsesiones: una manía, un juego numérico, una amante invisible, un acto heroico por realizar, un crimen deleitable o por cometer, una tradición ancestral, un dicho de infancia. Es en este terreno donde hay que buscar el tema encantatorio [mágico]. Una segunda combinatoria lo hará producir escenas con la fuerza poética que nace del sentimiento de estar en varios lugares a la vez, de la sensación de inestabilidad y de incertidumbre. Es de este modo que las imágenes podrán volverse al mismo tiempo abstractas y concretas, arquetípicas y cotidianas, plurales e intensamente concretas. Imágenes invocatorias y evocatorias a la vez (Ruiz, 129).

Por más que en el momento de comenzar una película se tengan ideas claras, será conveniente — sugiere Ruiz - partir siempre de encadenamientos, de asociaciones de imágenes simples, de concatenaciones y de imantaciones, de manera que veamos crecer el film por «arborescencias», por agenciamientos en forma de red o de entramados.

Cada una de esas figuras ofrece posibilidades propias que se pueden combinar a gusto, según el designio de las figuras mismas o el del filme. Con el fin de desarrollar este corpus de imágenes, es que Ruiz nos propone atenernos al así llamado «paradigma recursivo». Apelar a un paradigma recursivo quiere decir aquí, en primer lugar, progresar en el film, real o mentalmente, dando sentido al encadenamiento de parejas de objetos, uno de los cuales asumirá respecto del otro la función de fondo. Implica, enseguida, hacer que contra un fondo se destaquen pares de aquellas parejas de objetos (situación latente) y así sucesivamente, hasta obtener combinaciones cada vez más complejas, junto 
con prever siempre la posibilidad de volver atrás con frecuencia. De lo que se trata, por supuesto, es de "no perder el hilo", pero también de descubrir cada vez nuevos hilos conductores.

Al respecto, Raúl Ruiz ha señalado en alguna conversación (Vásquez Rocca, «Coleccionismo y Genealogía») — acerca de objetos y ficciones - que cuando no está filmando películas, durante sus paseos compra objetos al azar. Y cuando ya ha juntado una cierta cantidad de objetos nuevos que excitan su curiosidad, comienza a jugar con ellos. Hace listas ${ }^{7}$, las ordena, las mezcla, luego aísla dos o tres objetos y trata de imaginar una escena con estos tres. Son ejercicios que hace regularmente. Todo eso, según sostiene, no sirve para nada - en el sentido productivo inmediato-, por ello lo pone de lado cuando escribe un guión, pero constituye un repertorio de historias hechas únicamente con objetos. Sin embargo, indica: «en el momento de la filmación, cuando ordeno todo lo que hay en el plano, recuerdo ciertos automatismos, pongo los objetos de una manera ya dramatizada porque está atravesada por el recuerdo de éstas micro-ficciones que he elaborado. Todos estos ejercicios me dan la sensación en un momento de estar listo. No es improvisación, es incluso lo contrario, pero al mismo tiempo excede el simple ámbito de lo que se cree querer decir».

Se requiere de un enorme trabajo de acumulación para conseguir la primera imagen de una película, aquella que actúa como imagen germinal. A partir de esta imagen germinal se articula la narración. Esto es fundamental para entender esta concepción postmoderna del cine, de la cual Ruiz ha hecho una verdadera profesión de fe: «es la imagen la que determina la narración y no al contrario» (Ruiz, 152).

En el mundo no hay figura desprovista de consistencia aunque esa figura no sea coherente con la imagen co-existente. Una vez compuesta esta imagen doble, podríamos olvidar un instante el plan secreto y utilizarla como el punto de partida de la película futura porque es efectivamente la imagen la que determina la narración y no a la inversa. Es a partir de esa imagen que se hará la película y no a partir del dispositivo narrativo que le es pre-existente.

$\mathrm{Al}$ respecto, otro director, como Wim Wenders - amigo y con quien Ruiz colabora en El estado de las cosas -, canonizado por la crítica como autor paradigmático de la postmodernidad, señala, refiriéndose a que sus historias comienzan siempre por imágenes:

En las películas, las imágenes no conducen necesariamente a otra cosa; están allí por ellas mismas. Creo que una imagen pertenece en primer lugar a ella misma [...] La manipulación, que es necesaria para moldear todas las imágenes de una película en una historia, no me agrada; es muy peligrosa para las imágenes, pues absorbe tendencialmente lo que éstas tienen de 'vida'. En la relación entre la historia y la imagen, estas últimas [las imágenes] no quieren trabajar como vehículo, no quieren llevar ni transportar nada: ni mensaje ni significación ni propósito ni moral. Pero es precisamente eso lo que quieren las historias.

El cine de Ruiz es barroco en su forma, pero claramente posmoderno en su articulación narrativa y en sus ejercicios desmanteladores, en los que proliferan los juegos de espejos, los pasadizos secretos — en los que se entra y sale de una película a otra- en fin, las operaciones combinatorias.

En la obra de Georges Perec — a quien Ruiz refiere-, en una reiteración obsesiva de [sus] descripciones, enumeraciones y clasificaciones de objetos se puede advertir un fijar la atención minuciosa y escrutadora sin menoscabo del carácter provisorio que bajo su mirada adquiere cualquiera realidad. 
Por otro lado, el lenguaje fílmico define el plano secuencia como una unidad en sí, que comienza y termina, que suele ser largo, pero a veces puede ser muy corto. Se trata de una escena completa, se contradice con el plano que viene después que choca, que colisiona, que no quiere desaparecer para hacer aparecer el otro. Hay una película de Jean Louis Straw que se llama Las nubes y la resistencia, en que el fundamento mismo de la película es el plano secuencia. En ese filme la toma muestra a alguien leyendo un libro. Empezamos a verlo leer el libro, a escuchar lo que dice, y al cabo de tres minutos la cámara se mueve hacia la izquierda; ve el paisaje. En ese paisaje las cosas de las que habla el libro han sucedido. Está el dicho, y el lugar donde las cosas sucedieron. La cámara da la vuelta completa y lo retoma por el otro lado. Esta operación dura dos minutos y medio aproximadamente. Nos quedamos escuchando este personaje que sigue hablando, y ya nos comenzamos a aburrir con lo que dice. Escuchamos a ratos, la cámara sigue moviéndose y en un momento dado se empieza a ver el lugar en que está, más que a escuchar lo que dice. Cuando eso pasa cuatro veces, está la gente que se va y está la gente que se queda... - señala Ruiz - que descubre que ha pasado, como quien dice, a un nivel superior, esa toma es una película en sí. A esta sensación se refiere la así llamada función centrípeta en el cine.

Hay extremos, películas hechas de una sola toma. Por ejemplo, de una hora veintisiete, tal vez lo más innovador que se ha hecho en años, está El arca rusa. Hay también una película de Michael Snow, realizador canadiense que se llama La región central y que dura siete horas con una cámara que da vueltas sin parar en un solo lugar. Pasa el día, llega la noche, sale el sol, la gente transita y se pone a dormir, despierta, se toma una cerveza, mira... Es una experiencia que algunos aceptan y otros no, pero esa experiencia, esa sensación de quedarse en un mundo cerrado y no querer pasar a otra toma, se puede hacer con tomas mucho más cortas, que no vayan más allá de veinte a treinta segundos.

Pero existe otra función bastante más curiosa que podríamos llamar, siguiendo la clasificación propuesta por Ruiz, holística. Una función que presupone una estructura más compleja. Hablamos de una función holística en un plano cuando tenemos la impresión de que en un solo plano está la totalidad de la película. Los lectores de Proust recordarán que basta leer tres o cuatro páginas para tener la impresión de haber leído veinte volúmenes, no solo porque se hayan aburrido mucho, sino también porque a Proust se lo puede leer cincuenta veces, cien veces y cada vez se lee un libro distinto, porque cada vez se salta páginas distintas.

Esa sensación, implica que en una sola imagen de pronto se sienta toda la película; la pretensión de Ruiz, es que esto se pueda hacer con todas y cada una de las tomas de un filme.

No obstante hay otra función más, que se revela tan importante como esa, la función combinatoria. Se da cuando, después de haber visto unas cuantas tomas de la película, se inventan otras maneras de montarla, de organizarla. Una costumbre que se adquiere viendo reiterada en vídeo una escena que gusta mucho. La tienen también los que hacen zapping, es decir, pasan de un canal a otro haciendo - desapercibidamente- una combinación de tomas.

Una película filmada jugando con ciertas inadecuaciones de la continuidad puede permitir que constantemente, mientras se la ve, se estén combinando películas nuevas. Nótese que no estoy hablando de la idea de que el espectador debe ser autor de la película, sino que de una combinatoria que esté ya en esa película, que pueda ser integrada a 
las otras funciones anteriores: a la que cuenta una sola historia, a la que trata de quedarse dentro de la toma, y a la que una sola toma alude a la totalidad de la película.

Hay pues en el cine de Ruiz un arte combinatorio, frecuencias temáticas que se estructuran de manera tal que basta con combinarlas con otras, para que de este modo se revelen aspectos inesperados de la narración.

El cine de Ruiz es un particular modo de escritura, una de las retóricas de la posmodernidad, un territorio de ficción circunscrito por un lenguaje, su historia y sus resonancias. Como texto su estructura aparece como un juego de intermitencias, como un sistema de entreaberturas - pasadizos - y de guiños, de apariciones-desapariciones, de voluntad desmanteladora en beneficio del fragmento y de las historias dentro de las historias.

La estrategia deconstructiva de Ruiz consiste en proponernos como cebo narrativo de toda narración posible, el que una historia «fantasma» - impostora- permanezca «legible».

\section{7.- CINE, NARRATIVA Y METAFÍSICA DE LA VOLUNTAD}

La teoría del conflicto central y lo que de ella se deriva, está, según Ruiz, relacionada con ciertas discusiones sobre el determinismo y la libertad, la posibilidad de un individuo de escoger su propio destino. El mundo no es un puro conjunto de hechos de voluntad. Siempre hay un juego entre lo que se quiere y los accidentes. El que tiene en cuenta el azar y es capaz de equilibrarlo con la voluntad, puede dar un cine muy distinto del norteamericano, en el que solo juega la voluntad. Hay un cine, también, que hace exactamente lo contrario del cine norteamericano: viene del folletín del siglo diecinueve que conocemos viciado en las telenovelas, que constituyen una lógica narrativa alternativa. Allí en el folletín, dada una situación se hacen las inferencias, se sacan las consecuencias. La gente debe interesarse en cómo van a pasar las cosas pero ya conoce el final.

Con Kafka, la versión abstracta de este sistema, sucede lo mismo: se sabe ya que el agrimensor nunca llegará al castillo.

Si volvemos al cine, en particular al género del melodrama, donde Fassbinder, aun siguiendo a los maestros como Douglas Sirk, supo imponer su sistema narrativo, sus obsesiones y sus demonios, podemos decir que encontramos un esquema similar, por cierto propio del melodrama; el sentimiento de fatalidad, que convierte en vana agitación la lucha de sus personajes para evitar desenlaces que ya están decididos. Desenlaces de un drama previamente inmovilizado: donde el conflicto es mera ilusión.

Ahora bien, el feroz apetito de este concepto depredador va mucho más allá y constituye un sistema normativo. Una lógica como moral de la realidad o en último término de la narratividad. Sus conceptos han invadido la mayor parte de los centros audiovisuales; posee sus propios teólogos e inquisidores, así como su policía del pensamiento y la creación. Desde hace algún tiempo toda ficción que contravenga aquellas reglas será juzgada como condenable. Sin embargo no hay equivalencia entre la teoría del conflicto y la vida cotidiana. 
Es cierto que las gentes se baten en pugnas y entran en competencia; pero la competencia no tiene la capacidad de concentrar en torno a ella la totalidad de los sucesos que le conciernen, no posee tal peso gravitatorio.

Examinemos la cuestión, veamos el tema de la elección; se trata de escoger - la paradoja de la libertad en Sartre-. No nos queda más que escoger; actuar; el personaje no puede cancelarse y volver a su casa, en cuyo caso no habría historia.

Pero el problema es más complejo, no es solo cómo se constituye la historia a partir de la elección, sino si hay más de una historia posible para el universo, en este caso. Cuestión que también — si seguimos a Schopenhauer- es una ficción, dado que la pregunta decisiva que aquí se impone es si podemos querer, en el sentido de elegir lo que queremos.

Pero antes de terminar, es necesario hacer una última consideración en torno al tema de la decisión, y una confesión. Parafraseando a Ruiz cabe decir que cada decisión esconde otras más pequeñas — puede ser cínico o irresponsable- pero no se puede dejar de pensar que al tomar una decisión — por ejemplo, la de encontrarnos aquí escribiendo este artículo- esta misma esconde una serie de otras decisiones que nada tienen que ver con ella. Nuestra decisión es un disfraz y tras ella reina la indeterminación, lo aleatorio y azaroso.

\section{REFERENCIAS}

Aumont, Jacques. Las teorías de los cineastas (Les théories des cinéastes). Barcelona: Editorial Paidós. Medio impreso

Baudrillard, Jean. La Ilusión Vital. Barcelona: Editorial Anagrama, 2005. Medio impreso

-. Cultura y simulacro. Barcelona: Kairós, 1993. Medio impreso.

Cavallo, Ascanio y Antonio Martínez. Cien años claves del cine. Santiago: Planeta, 1995. Medio impreso.

De los Ríos, Valeria e Iván Pinto (Eds.). El cine de Raúl Ruiz, Fantasmas, simulacros y artificios. Santiago: Uqbar Editores, 2010. Medio impreso.

Derrida, Jacques. Márgenes de la filosofía. Madrid: Cátedra, 1988. Medio impreso.

Diéguez, Antonio. "La ciencia desde una perspectiva postmoderna: Entre la legitimidad política y la validez epistemológica». II Jornadas de Filosofía: Filosofía y política, Coín, Málaga: Procure, 2006. Medio impreso.

Foucault, Michel. Las palabras y las cosas, París: Gallimard, 1966. Medio impreso.

Lyotard, Jean-François. La condición postmoderna: Informe sobre el saber. Madrid: Cátedra, 1987. Medio impreso.

Mouesca, Jacqueline. Plano secuencia de la memoria de Chile. Madrid: Ediciones del Litoral, 1988. Medio impreso.

Ortega y Gasset. J. «El origen deportivo del Estado». Obras Completas. Volumen II. Madrid: Revista de Occidente, 1996. Medio impreso.

Parra, Nicanor. «Discurso de Guadalajara». En Jaime Quezada (comp). Nicanor Parra tiene la palabra. Santiago: Alfaguara, 1999. Medio impreso.

Ranciere, Jacques. La fábula cinematográfica. Barcelona: Ediciones Paidós Ibérica, 2005. Medio impreso. 
Robbe-Grillet, Alain. «Nouveau Roman: hier, aujourd'hui». En coloquio de Cerisy-lasalle, U.G.E., tomo 2. (1972), 10-18. Medio impreso.

Rojas, Waldo. «Raúl Ruiz: imágenes de paso; código interruptus». Raúl Ruiz. Alcalá de Henares: Ed. Filmoteca Nacional Alcalá de Henares, 1983. Medio impreso.

Rorty, Richard. Contingencia, ironía y solidaridad. Barcelona: Editorial Paidós, 1996. Medio impreso.

Rosenbaum, Jonathan. «Mapping the territory of Raúl Ruiz». Modern Times (1990). Medio impreso.

Ruiz, Raoul. La Poética del Cine. Santiago: Editorial Sudamericana, 2000. Medio impreso.

Las Tres Coronas del Marinero (Les trois couronnes du matelot). Ruiz, Raoul, dir. Films A2 / INA, 1983. Medio fílmico.

Ruiz, Raoul. Revista Cahiers du Cinéma. Número especial 345 (1983). Medio impreso.

Toubiana, Serge. «El caso Ruiz». Revista de Cine Enfoque, Ediciones del Instituto Chileno Canadiense de Cultura 1 (1983). Medio impreso.

Vásquez Rocca, Adolfo. «Coleccionismo y genealogía de la intimidad». En Almiar, Margen Cero, 2004. Sitio web.

-. «La Posmodernidad; nuevo régimen de verdad, violencia metafísica y fin de los metarrelatos». NÓMADAS 28 (2010). Medio impreso.

—. «Raúl Ruiz: La Recta Provincia y la invención de Chile». En Le Cinéma de Raoul Ruiz, 2007. Sitio web.

—. «Raúl Ruiz; L’enfant terrible de la Vanguardia parisina». En Almiar, Margen Cero, 2005. Sitio web.

Recepción: 19 de abril de 2010

Aceptación: 7 de junio de 2010 